\title{
Production of polyhydroxybutyrate and hydroxyapatite (PHB/HA) composites for use as biomaterial
}

\section{(Produção de compósito de poli-hidroxibutirato e hidroxiapatita (PHB/HA) para utilização como biomaterial)}

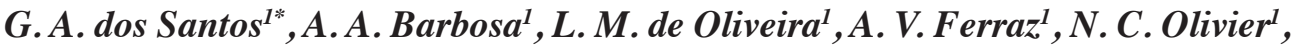 \\ W. Acchar ${ }^{2}$,A.C.S. Dantas ${ }^{1}$ \\ ${ }^{1}$ Universidade Federal do Vale do São Francisco, Juazeiro, BA, Brasil \\ ${ }^{2}$ Universidade Federal do Rio Grande do Norte, Natal, RN, Brasil \\ *Prof_geciane@hotmail.com
}

\begin{abstract}
The composite materials using polyhydroxybutyrate as matrix and hydroxyapatite as reinforcement (PHB/HA) were produced by molding, using pressing at $100 \mathrm{MPa}$ and $165^{\circ} \mathrm{C}$ for $30 \mathrm{~min}$. The amount of filler was varied from 0 to $20 \mathrm{wt} \%$ to evaluate the effect of the HA particles on mechanical properties and the bioactivity of the composites. The increase of the HA amount reduced the compressive strength of the composites nearly $20 \%$ while bending strength reduced nearly $30 \%$. However, the bioactivity after 14 days immersion in SBF was improved with the increase of HA amount, with formation of apatite layer on the surface of the PHB/HA composite.
\end{abstract}

Keywords: polyhydroxybutyrate, hydroxyapatite, composite, biomaterials.

\section{Resumo}

\begin{abstract}
Materiais compósitos com matriz de poli-hidroxibutirato e material de reforço de hidroxiapatita (PHB/HA) foram produzidos por moldagem a partir de prensagem em $100 \mathrm{MPa}$ e $165{ }^{\circ} \mathrm{C}$ durante $30 \mathrm{~min}$. A quantidade de reforço variou de 0 a $20 \%$ em massa para avaliar o efeito das partículas de HA nas propriedades mecânicas e na bioatividade dos compósitos. O aumento da quantidade de HA reduziu a resistência à compressão dos compósitos em aproximadamente $20 \%$, enquanto a resistência à flexão diminuiu $30 \%$. No entanto, a bioatividade após 14 dias de imersão em SBF foi melhorada com o aumento da quantidade de HA, sendo observada camada de apatita na superfície do compósito PHB/HA.
\end{abstract}

Palavras-chave: poli-hidroxibutirato, hidroxiapatita, compósito, biomateriais.

\section{INTRODUCTION}

Many biofunctional materials have been studied to improve their use as bone substitute. These materials exhibit properties which enhance the healing process [1]. Polyhydroxybutyrate (PHB) is an aliphatic polyester produced by microorganisms under unbalanced growth conditions [2, 3]. It is generally biodegradable (via hydrolysis) and thermoprocessable, making them attractive as biomaterials for applications in medical devices and tissue engineering. PHB decomposes to 3-hydroxybutyric acid (3HB), a normal constituent of human blood that evidences the high biocompatibility and non-toxicity of this polymer [4]. Recent studies also showed that $3 \mathrm{HB}$ molecules increase calcium influx in the cultured cells, suppress the death of cells, and prevent apoptosis induced by serum withdrawal $[5$, 6]. PHB is of particular interest for bone tissue application as it was demonstrated to produce a consistent favorable bone tissue adaptation response with no evidence of an undesirable chronic inflammatory response after implantation periods of up to 12 months. Bone is formed close to the material and subsequently becomes highly organized, with up to $80 \%$ of the implant surface lying in direct apposition to new bone [7]. PHB-based biomaterials have also been related to be piezoelectric and promote bone growth in vivo $[8,9]$.

Around $60 \mathrm{wt} \%$ of bone is made of hydroxyapatite [HA, $\left.\mathrm{Ca}_{10}\left(\mathrm{PO}_{4}\right)_{6}(\mathrm{OH})_{2}\right]$ and therefore $\mathrm{HA}$ has been intensively investigated as the major component for scaffold materials in bone tissue engineering [10]. HA has a close chemical resemblance to mineral part of the bone and consequently presents excellent biocompatibility [11]. However, its low fracture toughness limits the application at load-bearing sites. The high tensile strength and fracture toughness of cortical bone are attributed to the tough and flexible collagen fibers reinforced by HA crystals. Hence, calcium phosphates alone cannot be used for load-bearing scaffolds. However, its use as reinforcement of composite materials becomes very interesting to imitate the natural bone properties. The rheological and thermal properties of PHB can be tailored by incorporating appropriate amounts of 
HA. The HA particles can modify the surface chemically and physically, so that samples with high content of HA tend to exhibit pronounced differentiation resulting from high surface roughness and large amount of exposed HA [12]. The mechanical properties of PHB/HA scaffolds have been reported to be higher than those for pure PHB depending on the HA amount, the distribution of the particles in the matrix, the method used to conform the scaffold and the kind of mechanical property evaluated [13-16]. The goal of this work was to produce composite materials using PHB as matrix and HA as filler and evaluate the influence of the HA amount on the mechanical properties and bioactivity of the composites.

\section{MATERIALS AND METHODS}

Production of the composites: an aqueous $0.2 \mathrm{M}$ hemihydrated gypsum suspension $\left[\mathrm{Ca}(\mathrm{SO} 4) .1 / 2 \mathrm{H}_{2} \mathrm{O}\right]$ was reacted with $0.12 \mathrm{M}\left(\mathrm{NH}_{4}\right)_{2} \mathrm{HPO}_{4}$ solution to precipitate hydroxyapatite (HA) powders with molar $\mathrm{Ca} / \mathrm{P}$ ratio of 1.667 at $\mathrm{pH} 9.5$ according to Equation $\mathrm{A}$. A $3 \mathrm{M} \mathrm{NH}_{4} \mathrm{OH}$ solution was used to control de $\mathrm{pH}$ of the reaction. The precipitated powders were filtered and dried for $24 \mathrm{~h}$ and the dried powders were calcined for $2 \mathrm{~h}$ at $900{ }^{\circ} \mathrm{C}$ in air atmosphere. The PHB, produced from the Wautersia eutropha bacteria, was provided by PHB Industrial. The PHB was purified using the extraction Soxlether, using ethanol as solvent according to [17]. The HA and PHB powders were drymixed in varying amount of HA particles: PHB (0\% HA), PHB/HA-10 wt $\%$ and PHB/HA-20 wt $\%$. Subsequently the mixtures were warm pressed at $165^{\circ} \mathrm{C}, 5^{\circ} \mathrm{C}$ below the melting temperature, and $100 \mathrm{MPa}$ for $30 \mathrm{~min}$.

$$
\begin{aligned}
& 10 \mathrm{CaSO}_{4} \cdot \frac{1}{2} \mathrm{H}_{2} \mathrm{O}+6\left(\mathrm{NH}_{4}\right)_{2} \mathrm{HPO}_{4}+8 \mathrm{NH}_{4} \mathrm{OH} \rightarrow \\
& \mathrm{Ca}_{10}\left(\mathrm{PO}_{4}\right)_{6}(\mathrm{OH})_{2}+10\left(\mathrm{NH}_{4}\right)_{2} \mathrm{SO}_{4}+11 \mathrm{H}_{2} \mathrm{O}
\end{aligned}
$$

Composite characterization: mechanical strength testing was carried out in a standard test device (Emic, DL 10000) with a constant cross-head speed of $1 \mathrm{~mm} / \mathrm{min}$. For the compressive tests, a $5 \mathrm{kN}$ load cell and specimens with a diameter of $10 \mathrm{~mm}$ and height of $20 \mathrm{~mm}$ were used. The bending tests were performed according to DIN 843-1 using a $0.5 \mathrm{kN}$ load cell and specimens of $60 \mathrm{~mm} \times 10 \mathrm{~mm} \times 10$ $\mathrm{mm}$. Micrographs were obtained using a scanning electron microscope (SEM, Hitachi, TM-1000, Tabletop Microscope), using at least five micrographs for the measurement of the particle size. Fourier-transform infrared spectroscopy (FTIR) measurements were performed in a Bruker, FS66 spectroscope. The samples were prepared using $\mathrm{KBr}$ pellet, and the spectra were obtained in the range from 4000 to 500 $\mathrm{cm}^{-1}$. X-ray diffraction analysis (XRD, Siemens, Difract ACT 1000) was operated with monochromated $\mathrm{CuK \alpha}$ radiation $(\lambda=1.54056 \AA)$.

In vitro analysis: simulated body fluid (SBF) was prepared according to literature [18]. In vitro analysis was performed by immersion of the samples in SBF solution at controlled temperature of $36.5 \pm 0.5^{\circ} \mathrm{C}$ and $\mathrm{pH}=7.4$ for
14 days. The solution was changed every $48 \mathrm{~h}$ and the dimension of the samples was $5 \mathrm{~mm} \times 5 \mathrm{~mm} \times 50 \mathrm{~mm}$. After the immersion time, the samples were washed in deionized water and dried at $50{ }^{\circ} \mathrm{C}$.

\section{RESULTS AND DISCUSSION}

Characterization of the raw materials: Fig. 1 A shows the micrograph of the HA powder after calcination at $900{ }^{\circ} \mathrm{C}$, where big plate-like agglomerates can be observed. These agglomerates were formed by small HA particles. The X-ray pattern is shown in Fig. 1B. HA peaks and $\beta$-tricalcium phosphate $\left[\beta-\mathrm{TCP}, \mathrm{Ca}_{3}\left(\mathrm{PO}_{4}\right)_{2}\right]$ peaks were observed; however, no gypsum peak was detected. The formation of $\beta$-TCP can be associated to the reduction of the $\mathrm{pH}$ during the reaction, due to formation of sulfuric acid during the reaction. However, $\beta$-TCP is a resorbable biomaterial and enhance the biological properties of monolithic HA
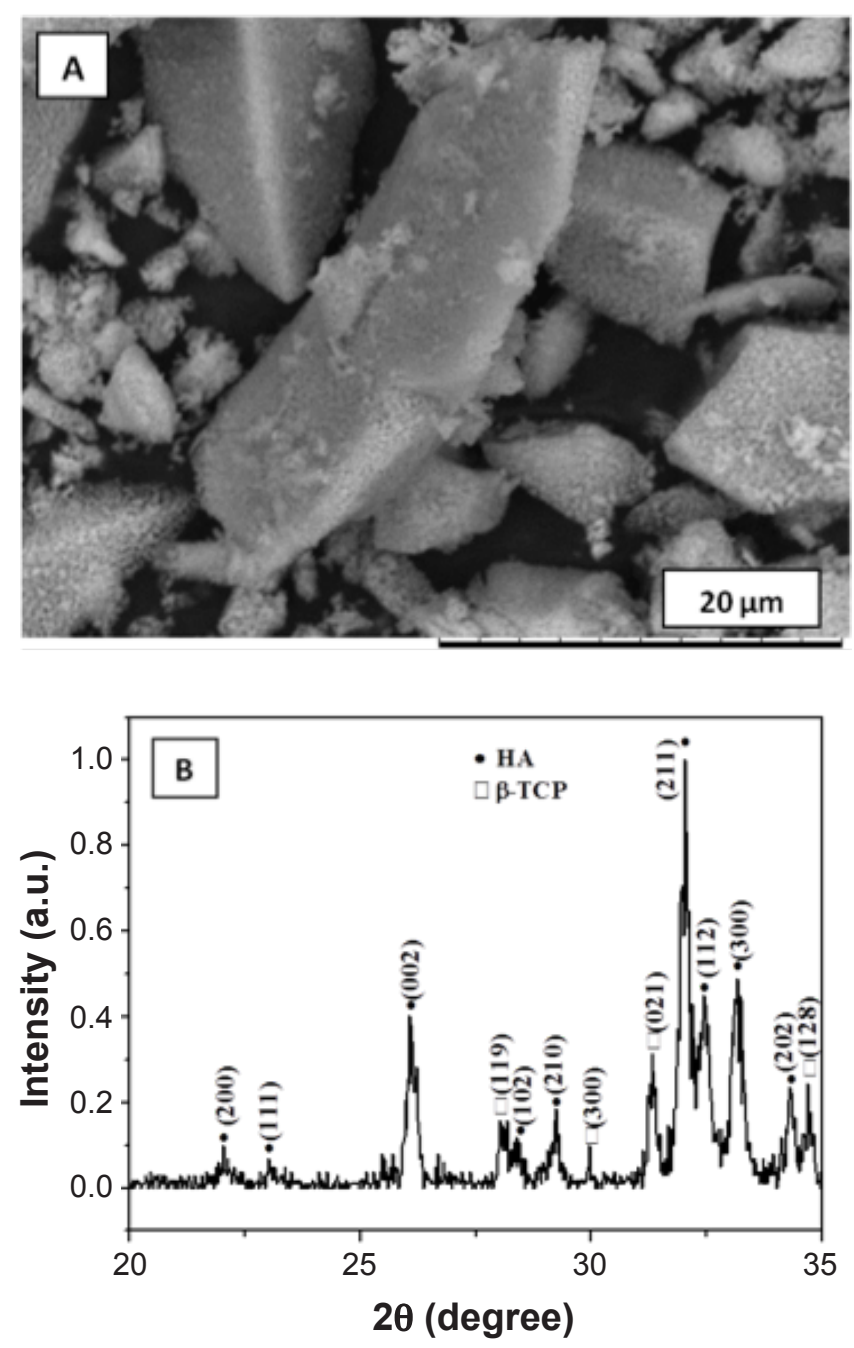

Figure 1: SEM micrograph showing the morphology of the particles (A), and X-ray diffraction pattern (B) of the HA powder after calcination at $900{ }^{\circ} \mathrm{C}$.

[Figura 1: Micrografia obtida por microscopia eletrônica de varredura mostrando morfologia das partículas $(A)$ e difratograma de raios $X(B)$ do pó de HA após a calcinação a $900{ }^{\circ} \mathrm{C}$.] 

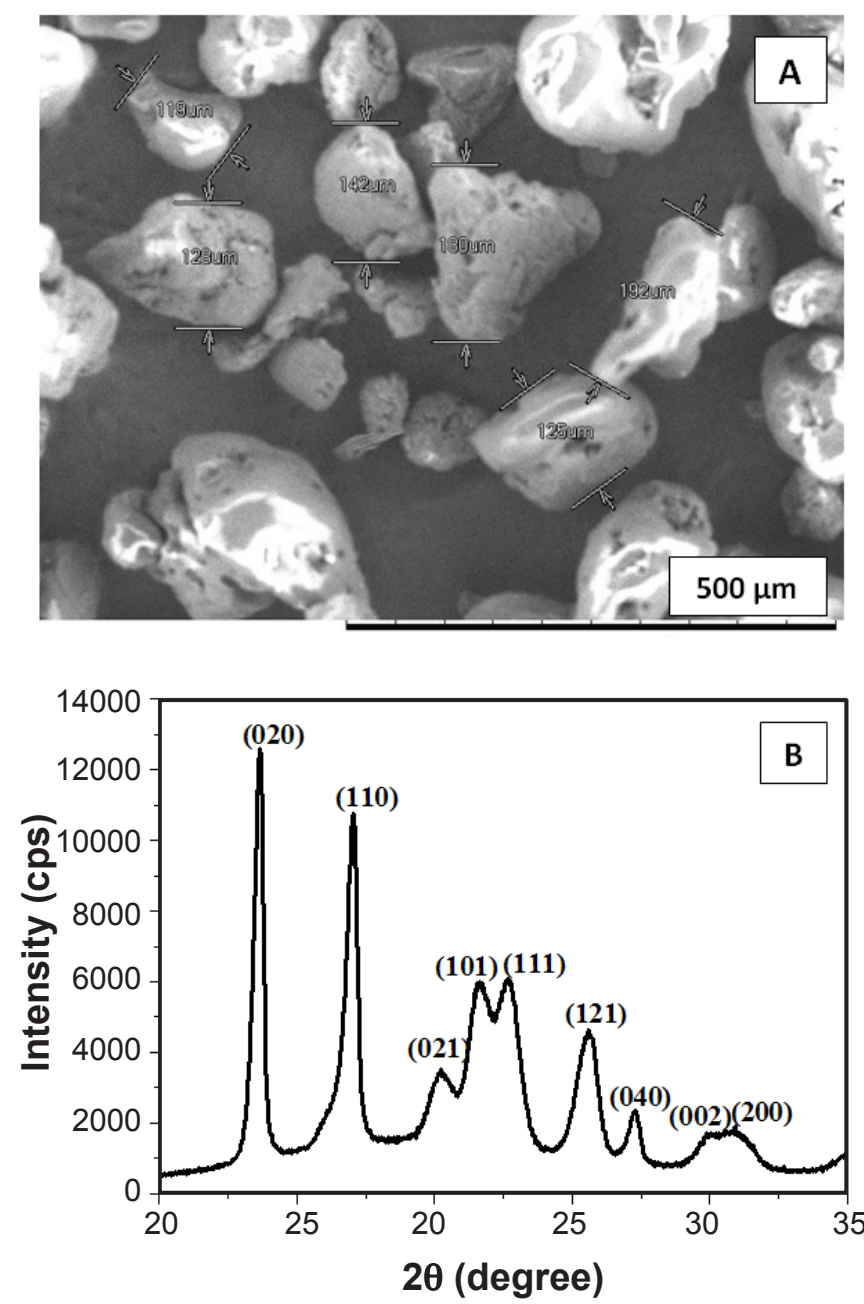

Figure 2: SEM micrograph showing the morphology of the particles (A), and X-ray diffraction pattern (B) of the PHB powder.

[Figura 2: Micrografia obtida por microscopia eletrônica de varredura mostrando morfologia das partículas $(A)$ e difratograma de raios $X(B)$ do pó de $P H B$.]

$[18,19]$. Micrograph of PHB particles is shown in Fig. 2A. An average particle size of $196 \mu \mathrm{m}$ was measured and the PHB particles showed an irregular morphology. PHB is a crystalline polymer, the XRD pattern is shown in Fig. 2B, where intense peaks relating to PHB can be observed. The more intense peaks were observed at $2 \theta=13.6^{\circ}$ and $17.1^{\circ}$, related to the PHB lattice planes (020) e (110), respectively. PHB showed crystallinity of $51 \%$, in accordance to others works that reported PHB crystallinity between 50 and $80 \%$ [20].

Mechanical characterization of the composites: Fig. 3 shows the results of mechanical properties of the composite samples with different HA amounts. The samples without HA reached the highest compressive strength, $\sigma_{c}$ of $23.7 \pm 2.1 \mathrm{MPa}$, and the highest bending strength, $\sigma_{\mathrm{f}}$ of $1.05 \pm 0.12 \mathrm{MPa}$. The increase of the HA amount lead to decrease of the mechanical properties, such that the samples containing 10\% HA reached a compressive strength of $16.4 \pm 2.1 \mathrm{MPa}$ and a bending strength of $0.88 \pm 0.55 \mathrm{MPa}$. Increase of the HA amount to $20 \%$ lead to further decrease of the mechanical properties. The addition of
HA promoted a decrease of the mechanical strength probably due to a deficient load transmission between the ceramic and polymeric phase. Hayati et al. [16] described an increase of the mechanical resistance related to the addition of HA on a PHB matrix. Samples with 5 and 10 wt $\%$ HA reached increases of 20 and $50 \%$ on the compressive strength of porous $\mathrm{PHB} / \mathrm{HA}$ scaffolds, respectively. They related the increase on the mechanical properties to a homogenous distribution of the HA nanoparticles on the matrix. The increased interface area works like a reinforcement that improves the load transmission between the matrix and the ceramic nanoparticles. The final porosity was similar for all samples. Our results however showed a decrease on the mechanical properties, related with the increased size of the particles of approximately $5 \mu \mathrm{m}$, since a good distribution of the HA particles on the PHB matrix was achieved. Galego et al. [21] reported a compressive strength of $67 \mathrm{MPa}$ for
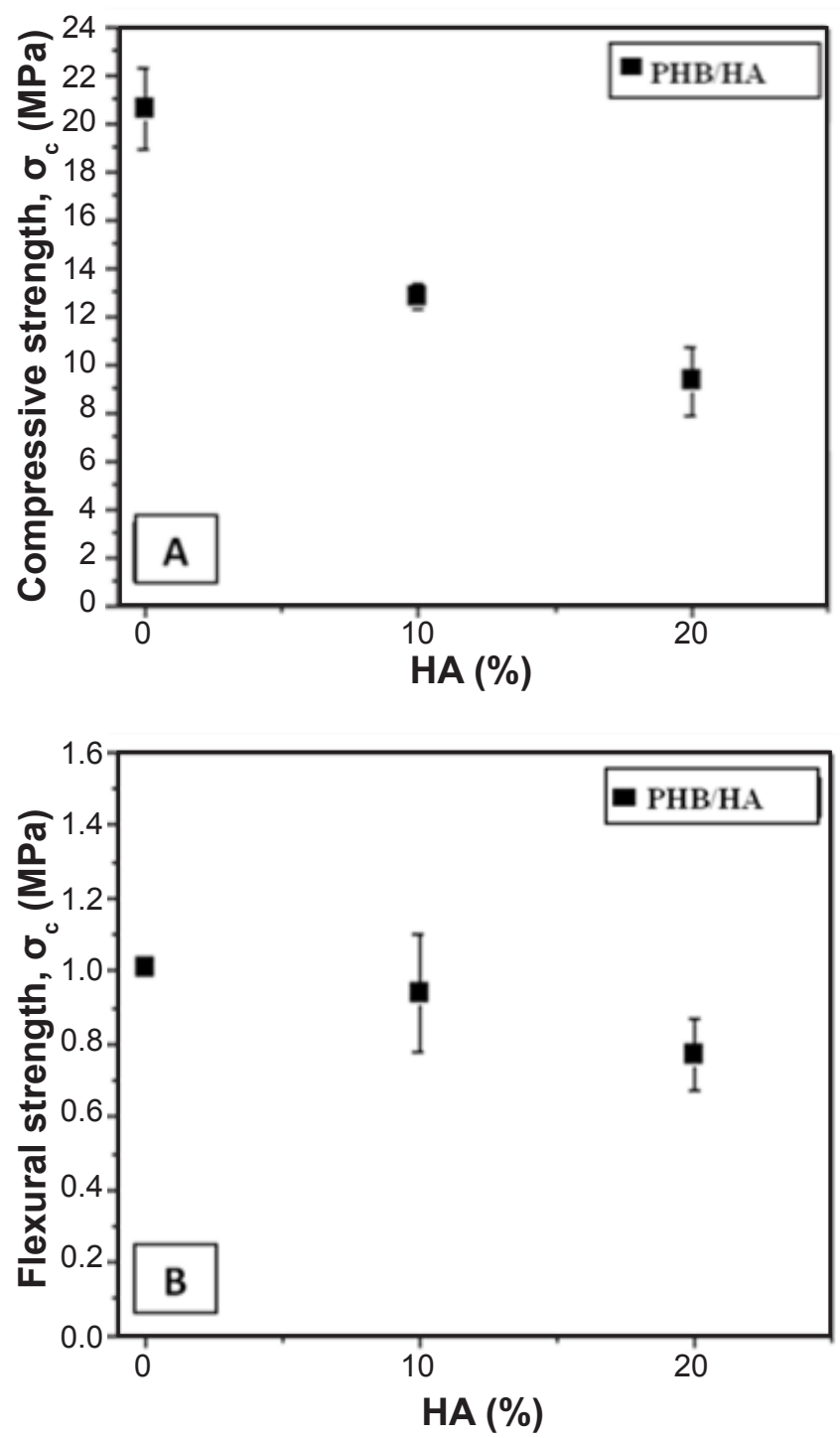

Figure 3: Results of mechanical tests of the PHB/HA composites: (A) compressive strength; and (B) flexural strength.

[Figura 3: Resultados de ensaios mecânicos dos compósitos PHB/HA: (A) resistência à compressão; $e$ (B) resistência à flexão.] 
PHB/HA composite with 30 wt\% HA. This sample was produced by pressing at temperature $5{ }^{\circ} \mathrm{C}$ above the melting point of the polymer. The compressive strength was measured on cylindrical samples of $8 \mathrm{~mm}$ diameter and $10 \mathrm{~mm}$ height, that tends to promote increased strength values; no porosity value was reported in the work.

Zhuo et al. [13] reported that HA could enhance the bending strength of HA/PHB composites. The HA content increased the bending strength until a HA content of 10 $\mathrm{wt} \%$ and the maximum bending strength reached was 32.74 $\mathrm{MPa}$, an increase of about $41 \%$ comparing with pure PHB. They also described that a further increase of the mechanical properties can be reached by addition of a silane coupling agent that improves the interface between the HA particle surface and the PHB matrix. Other works also presented increase of approximately $30 \%$ of the mechanical properties by addition of HA particles [14, 15]; in both cases the enhancement of the mechanical properties was related to the utilization of nanosized particles and the good distribution in the matrix. Doyle et al. [7] reported a reduction of the mechanical strength of PHB/HA composites by addition of HA particles. The composites were formed via injection molding of PHB and PHB/HA mixtures at $170{ }^{\circ} \mathrm{C}$. The in vitro and in vivo properties demonstrated a slow rate of degradation that may be controlled by reinforcement with HA particles. The tissue adaptation response to the PHB and PHB filled with 40 vol\% HA showed favorable to improve the bone healing. Under stresses, the dissipation of energy promotes a friction or damping in the polymeric material. In a polymer matrix composite, the energy dissipation may also come from the filler-matrix interface where friction between the two phases can occur. A high damping capability is accompanied by a decrease in dimensional stability. At the temperature of $165^{\circ} \mathrm{C}$, the addition of HA particles limited the mobility of the polymeric matrix and hence reduced the damping of the composites, the degree of which depended upon bioceramic volume percentage. An increase on the melting temperature of the PHB by addition of HA particles has been reported by Sadat-Shojai et al. [12] by use of DSC analysis to evaluate the melting of $\mathrm{PHB} / \mathrm{HA}$ composites with different HA contents. They related a shift of $10{ }^{\circ} \mathrm{C}$ on the melting temperature after addition of $20 \mathrm{wt} \%$ of HA.

In vitro analysis of the PHB/HA composites: SBF analysis confirmed that the addition of $10 \mathrm{wt} \%$ HA promoted an increase on the bioactivity of the samples in comparison with pure PHB. Fig. 4 shows the morphology of pure PHB
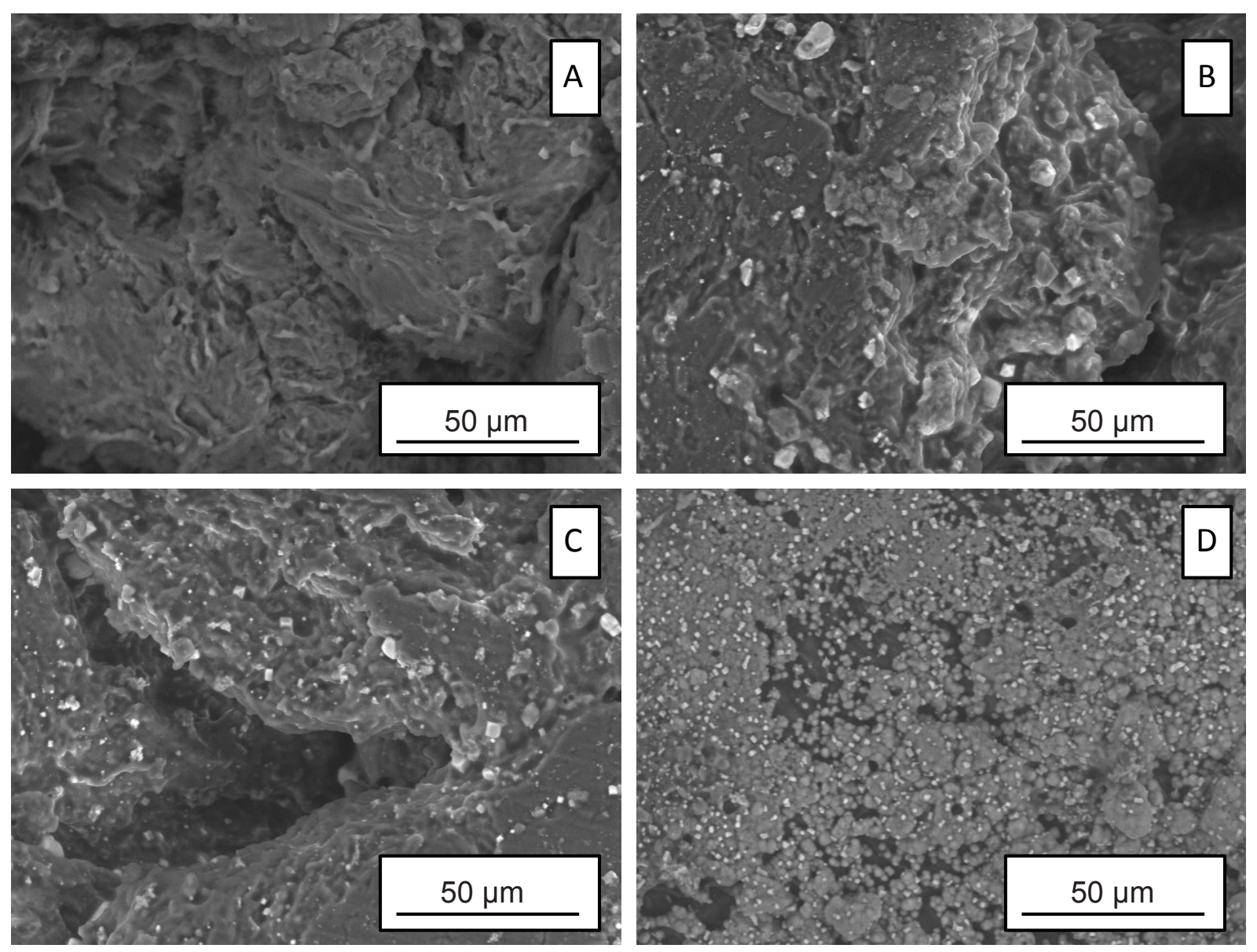

Figure 4: Surface morphology of the PHB sample before (a) and after immersion in SBF for 7 days (b), and of the PHB/HA sample with $10 \mathrm{wt} \%$ HA before (c) and after immersion in SBF for 7 days (d).

[Figura 4: Morfologia superficial das amostras de PHB antes (a) e após imersão em SBF por 7 dias (b), e de amostra de PHB/HA-10\% antes (c) e após imersão em SBF por 7 dias (d).] 
and PHB/HA-10 wt\% samples before and after immersion in SBF for 7 days. Only a small number of biomimetic HA crystals could be observed on the surface of the PHB sample after the immersion in SBF. The PHB/HA sample showed however more formation of biomimetic HA on their surface after immersion in SBF for 7 days. Studies have described formation of apatite crystals on the surface of PHB/HA composites after immersion in SBF. Ni and Wang [22] evaluated the effect of HA on the bioactivity of PHB using HA amounts of $0,10,20$ and 30 vol\% HA. It was observed formation of small crystals after 1 day immersion and more near-spherical crystals were observed on the specimen after 7 days immersion. The formation of a complete layer of apatite crystals was observed only after 7 days on all HA/PHB composites. Mineral crystals were also found on unfilled PHB after its immersion in SBF for 14 days, but the growth of these crystals was very slow. After 28 days immersion, the mineral layer formed was still very thin and rough and only after 56 days immersion was a uniform mineral layer observed. Szuberta et al. [23] studied the apatite layer formation on the surface of HA samples modified by incorporation of PHB. It was reported the formation of a layer with the near-spherical grains on the surface pellet of HA grafted by PHB after 28 days immersion in SBF. They reported that the mixture of PHB and HA can be more bioactive than pure HA, however no mechanism to explain this hypothesis was presented.

\section{CONCLUSIONS}

The addition of HA in the polymeric matrix of PHB promoted decrease of the mechanical strength of the PHB/HA composites, due to formation of discontinuities on the matrix promoted by poor interface between the matrix and the ceramic particles. However, the increase of the HA amount enhanced the bone-like apatite formation on the composite surface after immersion in SBF, which indicated an increase of the bioactivity.

\section{REFERENCES}

[1] H.K. Uhthoff, P. Poitras, D.S. Backman, J. Orthop. Sci. 11, 2 (2006) 118.
[2] Y. Doi, S. Kitamura, H. Abe, Macromol. 28, 14 (1995) 4822.

[3] H.Y. Li, R.L. Du, J. Chang, J. Biomater. Appl. 20, 2 (2005) 137.

[4] Y. Zhao, B. Zou, Z. Shi, Q. Wu, G.Q. Chen, Biomaterials 28 (2007) 3063.

[5] S. Cheng, Q. Wu, F. Yang, M. Xu, M. Leski, G.Q. Chen, Biomacromolecules 6 (2005) 593.

[6] S. Cheng, G.Q. Chen, M. Leski, B. Zou, Y. Wang, Q. Wu, Biomaterials 27 (2006) 3758.

[7] C. Doyle, E.T. Tanner, W. Bonfield, Biomaterials 12 (1991) 841.

[8] Y. Ando, E. Fukada, Polymer Phys. 22 (1984) 1821.

[9] S.K. Misra, S.N. Nazhat, S.P. Valappil, M. MoshrefiTorbati, R.J.K. Wood, I. Roy, A.R. Boccaccini, Biomacromolecules 8 (2007) 2112.

[10] R.Z. LeGeros, J.P. LeGeros, Bioceram. 15 (2002) 3.

[11] M. Jarcho, J.F. Kay, K.I. Gumar, R.H. Doremus, H.P. Drobeck, J. Biosci. Bioeng. 1, 2 (1977) 79.

[12] M. Sadat-Shojai, M.-T. Khorasani, A. Jamshidi, S. Irani, Mater. Sci. Eng. C 33 (2013) 2776.

[13] G.Z.Q. Zhuo, L.M. Dong, C. Wang, Q.F. Zan, J.M. Tian, Adv. Mater. Res. 105-106 (2010) 104.

[14] H.T. Jiang, P. Hu, L. Liu, Y. Li, Isinghua Sci. Technol. 7 (2002) 463.

[15] I.Y.-W. Wang, Q. Wu, J. Chen, G.-Q. Chen, Biomaterials 26 (2005) 899.

[16] J.A.N. Hayati, H.R. Rezaie, S.M. Hosseinalipour, Mater. Lett. 65 (2011) 736.

[17] H.C. Birnboim, J. Doly, Nucl. Acids Res. 7, 6 (1979) 1513.

[18] T. Kokubo, H. Takadama, Biomaterials 27 (2006) 2907. [19] M. Descamps, T. Duhoo, F. Monchau, J. Lu, P. Hardouin, J.C. Hornez, A. Leriche, J. Eur. Ceram. Soc. 28, 1 (2008) 149.

[20] M. Vallet-Regí, J.M. Gonzalez-Calbet, Prog. Solid State Chem. 32, 1 (2004) 1.

[21] N. Galego, C. Rozsa, R. Sánchez, J. Fung, A. Vázquez, J.S. Tomás, Polym. Test. 19 (2000) 485.

[22] J. Ni, M. Wang, Mater. Sci. Eng. C 20 (2002) 101.

[23] M. Szuberta, K. Adamskaa, M. Szybowiczb, T. Jesionowskia, T. Buchwaldb, A. Voelkela, Mater. Sci. Eng. C 34 (2014) 236.

(Rec. 28/09/2016, Rev. 05/02/2017, Ac. 10/03/2017) 